\title{
RENVOI DOES NOT INVOLVE A LOGICAL FALLACY
}

\section{Thomas A. Cowan $\dot{T}$}

Renvoi ${ }^{1}$ has been burned at the stake many times by the very ablest writers in the field of private international law. Yet, Phoenixlike it always arises from the ashes of its own holocaust. The continued existence of the doctrine should make one suspect that renvoi fills a vital practical need in the field of the conflict of laws. ${ }^{2}$ In fact it reconciles two contradictory principles of decision. The one is the conflict of laws rule which directs the court under certain general circumstances to apply foreign law. The other is the intuitive conviction of the judge that in the special circumstances of the renvoi case before him the ends of justice will be served just as well, if not better, by the application of the familiar law of the forum rather than the unfamiliar law of a foreign jurisdiction. Whether legitimate or not, renvoi is a device which permits both of these contradictory needs to be satisfied.

Renvoi has in the past occasioned little concern to American writers. Although potentially applicable on a vast scale to problems of conflicts in the laws of the various states of the Union, ${ }^{3}$ renvoi in

† B. S., I926, LL. B., I93I, Ph. D., r932, University of Pennsylvania ; S. J. D., I933, Harvard University; Instructor in Philosophy, University of Pennsylvania, 1926-1932; Attorney, U. S. Department of Justice, I934-I936; Associate Professor of Law at Louisiana State University.

I. The basis for the doctrine of renvoi was laid by the French Court of Cassation in the famous Forgo case, Administration des Domaines contra Ditchl et autres, Cour de Cassation, June 24, I878, Dalloz Recueil de Jurisprudence, I879 I. 56; Sirey, I882 I. 393. Forgo, a natural child, born Bavarian, died intestate at Pau leaving movable property in France. By the Bavarian law, collateral relatives had a claim. Under the Code Napoléon, these relatives were excluded. Inasmuch as Forgo had not obtained authorization to establish his domicile in France, French law referred the court to Bavarian law for rules governing the distribution of the estate. According to Bavarian law, on the other hand, questions of intestate succession were determined by the lex situs of the property, i. e., the law of France. The court held that French law was applicable, thus "accepting the renvoi" from the Bavarian law. Theoretical discussion appears to have been started by an article of Labbé entitled, Du Confit entre la Loi Nationale du Juge Saisi et une Loi Etrangère Relativement à la Determination de la Loi Applicable à la Cause (I885) I2 ClunET 5. A complete history of the Forgo case is given by Philonenko, L'Affaire Forgo (I932) 59 CLUNET 281.

Throughout this article, Journal dU Drort InTERnational Prive will be referred to as Clunet; the Revue De Droit International Prive and its continuation, the Revue CRITique de Droit International as DarRas; the Zeitschrift Fưr INTERNationales Privat und Strafrecht as Niemeyer; and JHerings Jamrbücher für DIE DogMatiK DES BÜrgerLICHEN RECHTS as JHERINGS JAHRBÜCHER.

2. The American Law Institute accepts the doctrine of renvoi as governing questions of title to land and those concerning the validity of divorce. RESTATEMENT, CONFLICT OF LAWS (I934) \$ 8 .

3. Professor Philonenko, in a recent very careful study, is struck by the fact that renvoi plays such an important part in the law of so many countries. He concludes that this cannot be the result of coincidence, but on the contrary is evidence of the operation of a general legal principle. LA Theorie du Renvor EN DroIt Compare (I935). See the recent case of University of Chicago v. Dater, 277 Mich. 658, 270 N. W. I75 (1936), where the court in effect applies the renvoi doctrine without mentioning it. The case is commented on by Thompson, Conflict of Lazes-Renvoi Theory -Conflicts Restatement (I937) 35 MICH. L. REv. I299, and noted in (I937) 2r MiNN. L. REv. 739. This case really turns on a point of qualifications. The doctrine of renvoi 
fact has received in this country only a modicum of the attention which is paid to it in England and on the Continent. Under the influence of the masterly attacks on the doctrine by Professor Lorenzen, ${ }^{4}$ aided by the tremendous authority of Professor Beale, ${ }^{5}$ the American writers seem, save for a recent break, unanimously agreed that renvoi is "no part of the Conflict of Laws of the United States".

The break referred to is Professor Griswold's recent article entitled "Renvoi Revisited". " In it Professor Griswold very definitely departs from the American tradition and accepts that form of the doctrine of renvoi which is actually applied by the English courts. This stand reopens an issue confidently regarded as closed by most American authorities on the conflict of laws, ${ }^{8}$ and it will doubtless serve to provoke discussion in this country on the troublesome and obscure subject of renvoi. It likewise renders timely the present writer's thesis that renvoi does not involve a logical fallacy. In "Renvoi Revisited", the learned writer concedes that fallacy to be at least a "remote possibility" 9 when renvoi is accepted. He thus limits the application of the doctrine to those cases where the fallacy is not a "possibility" and lays himself open to attack on the ground that the possibility of fallacy is not so "remote" as he would like to believe.

did not develop in connection with a conflict of qualifications. See Lorenzen, The Theory of Qualifications and the Conflict of Laws (1920) 20 CoL. L. REv. 247. Yet renvoi is a possibility whenever conflict of a choice of law exists. It is not restricted to a conflict of the law by which a case is to be finally adjudicated. In questions of status such as domicile, for example, there can well be a conflict of rules for determining when the status exists. The American rule may ascertain the fact of domicile by residence, and a foreign law by nationality. It is quite possible for renvoi to be applicable to this problem. Thereafter, if and when the fact of domicile is made out, a further problem remains. That is, having determined domicile, which law should be applied to dispose of the case? Hence, the terrifying possibility exists, in contemplation at least, of two renvoi situations arising in the same case. Fortunately, from the point of view of logic, there is no greater difficulty in dealing with two renvoi situations in one case than with one renvoi situation in two cases. The first is more complex, to be sure, but the complexity is legal and not logical. Professors Cheatham, Dowling and Goodrich draw attention to the question by asking, "What is the relation of the problem of renvoi to the problem of classification?" Cases AND OTHeR MAterials on Conflict of LAws (1936) 648. For a collection of references on the problem of qualifications see LoRenzen, Cases and Materials on the Conflict of LAws (4th ed. 1937) 46, n. 5I, and in particular, Bartin, De l'Impossibilité d'Arriver à la Suppression Définitive des Conflits de Lois (1897) 24 CluneT 225, 466. See also Falconbridge, Characterization in the Conflict of Laws (r937) 53 L. Q. REv. 235, 537; Conflict of Laws: Examples of Characterization (I937) I5 CAN. B. REv. 215; Niboyet, Froland, Les Conflits de Qualifications et la Question du Renvoi (I926) 2I DARRAS I. When the members of the bar become aware of the possibilities of applying renvoi to qualifications such as was done in effect in the Dater case, we may expect the problem to be presented in much general litigation involving the conflict of laws of the various states.

4. The Renvoi Theory and the Application of Foreign Law (19ro) no CoL. L. REv. 190, 327; The Renvoi Doctrine in the Conflict of Laws-Meaning of "The Law of a Country" (IgI8) 27 YALE I. J. 509.

5. Conflict of Laws (1935) \$7.3; Restatement, Conflict of Laws (1934) $\$ 7$.

6. Lorenzen, supra note 4, Io CoL. L. REv. at 344 . For a complete discussion of this concert of opinion, see Griswold, Renvoi Revisited (I938) 5I HARv. L. Rev. II65, pt. III.

7. Griswold, loc. cit. supra note 6.

8. See infra note I6.

9. Griswold, supra note 6, at II93. 
The doctrine of renvoi necessitates reference and counter-reference between the law of the forum and foreign law. From this there has arisen an assumption universally accepted by writers on the conflict of laws that such reference and counter-reference lead inescapably to some form of logical fallacy, ${ }^{10}$ whether a vicious circle, or an endless series of cross-declinations of jurisdiction, or an infinite regress of definitions, ${ }^{11}$ or an indefinite postponement of choice of the law by which the subject matter of the litigation is to be governed.

Those few writers who favor renvoi recognize the force of such opinion. In meeting it they strive either to minimize the importance of the supposed fallacy ${ }^{12}$ or else to invent expedients to circumvent it. ${ }^{13}$ Those who oppose renvoi naturally make much of the insecurity of its logical foundations. ${ }^{14}$ Logic is given by them as one, but by no means the only, reason why renvoi should be rejected as a general theory.

If it should be discovered, therefore, that the assumption that renvoi involves a vicious circle is without foundation, both the proponents and the opponents of the doctrine will be affected. The net result of this new position, if it is established, will be the elimination of the vicious circle argument from the field of controversy. The acceptance or rejection of renvoi must then be decided on juridical, not on logistic, grounds.

The writer expresses at this time no opinion on the merits of renvoi as a solution of those problems in the conflict of laws to which it has

Io. Reference here would be to well-nigh the entire body of theoretical literature on the subject of renvoi. I have come upon no writer who has denied that in one form or another renvoi leads to some sort of fallacy.

II. "From the logical point of view it is apparently not an instance of circular reasoning, but rather of a regression." Griswold, supra note 6 , at II $67, \mathrm{n} .8$.

12. "So we see, that by approaching the matter from the abstract and theoretical point of view, the fear of the endless chain has been magnified into a generalization; while the endless chain is in fact and in practice an extremely rare apparition. Doubtless, we cannot leave this discussion without conceding that it may sometime appear. What will we do if we refer a question to the law of some other state and that state in turn refers it back to us and tells us that it will dispose of it as we do? One is tempted to follow the common-law tradition and say that it will be time enough to dispose of that question when it really arises. . . . In any event, the important thing to bear in mind is that the endless chain is a remote possibility, not the central theme of renvoi, and the possibility of its appearance should not be allowed to distort the law in the many cases where it is not present." Griswold, supra note 6, at II92-93.

I3. Westlake and von Bar, who favor the result attained by renvoi, seem to have agreed that infinite recurrence could not be escaped after the first reference. In order to avoid the vicious circle, they devised the ingenious hypothesis known as the theory of désistement, which supposes a mutual disclaimer of jurisdiction by both courts. The result is the application of the internal law of the forum. Westlake, PrTvate InTERNATIONAI LAW (7th ed. I925) 30-3I ; Von Bar (I900) I8 ANNUAIRE DE L'INSTITUT DE DroIT INTERNATIONAL 4I, I53 et seq. For a detailed criticism of this theory, see Lorenzen, supra note 4, 27 YALE L. J. at 512-5I8; Schreiber, The Doctrine of the Renvoi in Anglo-American Law (I9I8) 3I HARV. L. REv. 523, 529-32.

I4. The following is a good example of this type of argument against renvoi. "(a) It is illogical. No logical reason can be given why if in the one case . . . Massachusetts law be taken to refer to the French conflict-of-laws rule, the latter should not in turn be held to refer back again to the Massachusetts conflict-of-laws rule, and so on ad infinitum; ..." Schreiber, id. at 533 . 
been applied. It so happens, to be sure, that if the doctrine be purged of logical fallacy those who favor it gain. Yet from the viewpoint of analysis, this result is accidental, and commits the writer to no stand on the merits of the doctrine. Trouble enough remains for the proponents of renvoi even though they be relieved of the onus of paradox.

\section{Renvoi ${ }^{15}$}

Let us consider for a moment the following familiar hypothetical case which will serve as the basis of our discussion. Smith, an American citizen, dies in France leaving movable property in New York. At the time of his death, Smith was domiciled in France according to the law of New York but not according to the law of France. The law of New York directs the distribution of movables in accordance with the law of the domicile of the deceased. French law directs such distribution according to the law of the nationality of the deceased. The New York court is seised of the case.

It is apparent that the above case involves at least two types of law. I. The rule of conflict of laws which determines as a preliminary matter the choice of law by which distribution should be effected. This we shall call for convenience the conflicts rule. 2. The municipal or internal rules of law directing the actual distribution of the property. This we shall call the internal law.

A court faced with a case involving French and American conflicts rules and internal law has a choice of three ways to combine them. I do not intend to have it inferred that an actual case may not involve more than three possibilities of choice. I mean that in the hypothetical case set forth, together with as much law as I have indicated is relevant, at least these three possible ways of proceeding exist:

I. The judge may decide that the American conflicts rule refers him solely to French internal law. This is the position accepted by many French writers, by some English writers, and so far as I know, by all American authorities but one. ${ }^{16}$

I5. Throughout this article, the term renvoi is restricted to mean reference back or "remission" from one system of law to another. Notice will be taken of what has been called "transmission" (Weiterverweisung) from one system of law to another, thence to a third, only at the end of the article. See Bates, Remission and Transmission in American Conflict of Laws (I93I) I6 CoRN. L. Q. 3II ; Schreiber, supra note I3, at 525.

I6. At the meetings of the Institute of International Law held in 1898 and 1900 , the doctrine of renvoi was proposed and rejected. See (I897) I6 ANNUAIRE DE L'INSTITUT DE Droit INTERNational 47; (I898) I7 id. I4, 22; (1900) I8 id. 34, 145. The period witnessed a flood of literature on the subject of renvoi, most of it hostile to the doctrine. See Bartin, Les Conflits entre Dispositions Législatives de Droit International Privé (I898) 30 Revue de Drort INTERnatronal (I er série) I29, 272; Von Bar, Die Riickverweisung im internationalen Privatrecht (I898) 8 NIEMEYER I77; Asser, La Question du Renvoi devant la Trosième Conférence de Droit International Privé (Igoo) 2 Revue de Droit International (2e série) 316; Fiore, Du Confit entre les Dispositions Législatives de Droit International Privé (xgor) 28 CLUNET 424; Buzzati, Die Frage der Rückverweismg vor dem "Institut de Droit International" (I902) II NIEAIEYER 3; Ligeoix, La Théorie du Renvoi et la Nature Juridigue des Règles de Droit International Privé (1903) 30 ClUNET 48I; Asser, Quelques Observations Concernant 
2. The judge may decide that the American conflicts mule refers him to the French conflicts rule which, in turn, refers him solely to the American internal law. This is the doctrine of renvoi in its most usual form. It is the position steadfastly adhered to by the French Court of Cassation, ${ }^{17}$ is the view approved by certain English writers of note ${ }^{18}$ and by a few Continental writers of importance. ${ }^{19}$ It is part of the statutory law of Germany. ${ }^{20}$

3. Lastly, the judge may decide that the American conflicts rule refers him solely to the French conflicts rule which, in turn, refers him solely to the American conflicts rule. This results in a circulus inextricabilis since it indicates an infinite number of cross references. ${ }^{21}$

la Théorie ou le Système du Renvoi (1905) 32 CLUNET 40. Finally, the extensive treatise of Lainé condemning the doctrine appeared in four successive years, $L a$ Théorie $d u$ Rerrvoi (1906) 2 DarRas 605; (1907) 3 id. 43; (1908) 4 id. 729; (1909) 5 id. I2. The following year the French Court of Cassation rejected an appeal seeking to have renvoi abandoned. Hermann contra Soulié, Cour de Cassation, March I, I9Io, 37 ClUnet 888. This decision was roundly scored by Pillet, Contre la Doctrine du Renvoi (19I3) 9 Darras 5. Finally in the case of Guez contra Ben Attar, Cour de Cassation, Nov. 7, I933, Dalloz Recueil Hebdomadaire de Jurisprudence, I933 I. 570 (I935) 62 CiUNEr 88, the jurisprudence was fixed with seeming finality. The court even employed the word renvoi formally in its decision, thus indicating that there is little chance of its yielding to the critics of the doctrine. Nevertheless the French die hard. See criticism of renvoi in Perroud, Encore la Question du Renvoi (1937) 64 CuUnET 492. Niboyet seems to have yielded, though not without gloomy forebodings. Note (I936) 3I DARRAS I 55. The position of the Court of Cassation is defended by Pigeonniere, Observations sur la Question du Renvoi (I924) 5I Clunet 877. See also I ARMInjon, Précis de Droit International Priví (2d ed. I927) I49 et seq.; Le Renvoi (1922-23) I8 DARRAS 565 .

In England the doctrine of renvoi has been hammered incessantly. BATE, Notes on the Doctrine of Renvor (Ig04); Abbot, Is the Renvoi a Part of the Common Law? (Ig08) 24 L. Q. Rev. I33; BATY, Polarized LAw (I9I4) II5; Pollock, The 'Renvoi' in New York (I920) 36 L. Q. REv. 9I ; Falconbridge, Renvoi and Succession to Movables (I930) 46 L. Q. Rev. 465 ; (I931) 47 id. 27I ; CeEESHIRE, PRIVATE InTERNATIONAL LAW (2d ed. I938) 48. Yet the English courts adhere to their peculiar form of the doctrine. See infra note 2I. "The English judges and scholars, however, seem to be tending to accept the doctrine." Beale, The Conflict of Lazes, I886-1936 (I937) 50 HaRv. L. REv. $887,890$.

The American position is also succinctly stated by Beale. "American scholars have, almost without exception, rejected the doctrine as having no place in our law. . .." Id. at 889. See Restatement, Conflict of Laws (I934) $\$ 7$, comment $d$. The only American decision to come to my attention that expressly ruled upon renvoi rejected it. In re Tallmadge, Iog Misc. 696, 18I N. Y. Supp. 336 (Surr. Ct. I9I9).

17. Supra note I6.

18. Bentwich, The LaW of the Domicile in its Relation to Succession (I9II) I80, I8I ; DICEY, CONFLICT OF LAWS (4th ed. I927) app. n. I; WESTLAKE, op. cit. supra note 13, at 25 et seq.; Bentwich, Recent Application of the Renvoi in Matters of Personal Status (1936) I4 CAN. B. Rev. 379.

19. Supra note I6.

20. Art. 27, Introductory Acr, Civ. Code. Lewald, Das Deutsche InternaTIONALE PRIVATRECHT (1931), is opposed to renvoi. For references to the position of other foreign countries on this question, see LORENzEN, op. cit. silpra note 3 , at 52 ; Potu, La Question du Renvor en Drort International Privé (Igr3); Kahn, $A b$ handlungen aus dem internationalen Privatrecht (I899) 40 JHERINGS JAHRBÜCHER I, 56, n. I; Lorenzen, supra note 4, Io CoL. L. REv. at 327; Philonenko, La Théorie du Renvoi quant à la Loi Applicable à la Capacité des Personnes dans le Projet de Code de Droit International de l'Amérique Latine (I928) 55 CLUNET 3I5. Note (I926) 36 Y YLE
L. J. II4.

2r. I do not include as a separate method, the procedure adopted by the English courts. They interpret their conflicts rule to require the judge to dispose of the case 
The majority of law writers are in agreement that one who seeks to take the second position is inevitably forced back upon the third position. Their argument in effect is as follows. The American conflicts rule refers the judge either to French internal law solely or to what they call the whole of relevant French law including the conflicts rule. If the reference is to French internal law solely, we have the situation set forth under number $\mathrm{I}$. If, on the contrary, the reference is to the whole French law, then in all consistency, they say, the French conflicts rule must refer the matter to the whole American law, which in turn, through the operation of the American conflicts rule, must refer the matter to the whole French law, quod est absurdum. ${ }^{22}$

In partial answer, I may say that the use of the phrase "whole of French law" is confusing. There is no "whole" law to be applied. The French internal law and the French conflicts rule lead to different results. ${ }^{23}$ Hence a choice must be made between them. If in our case French internal law is chosen, there is an end of the matter. If, on the contrary, the French conflicts rule is chosen, the further question arises whether reference is back to American internal law or to the American conflicts rule. It is at this point that these writers deny that

as would a judge of the foreign country to whose law reference is made. The result is that if the foreign court would reject renvoi, the English court rejects it and applies its own law. In re Ross [I930] I Ch. 377. If, on the other hand, the foreign court would have accepted renvoi, the English court accepts it and applies foreign law. In re Annesley [1926] Ch. 692; In re Askew [1930] 2 Ch. 259. In the first endition of his book on PRIVAte International Law (1935) 138, Professor Cheshire states that this method made the doctrine of renvoi no longer of practical importance to English lawyers. Yet he concluded his discussion with the statement: "It would seem that the diffculty of the 'unending circle', which is said to characterize the doctrine of renvoi, equally afflicts the present doctrine-that an English judge must give the same decision as the Court of the domicil would give-if the lex domicilii happens to adopt the same attitude." Id. at $\mathrm{r} 4 \mathrm{I}$. In the second edition of the book, op. cit. supra note 16 , this equivocal position is abandoned; and Professor Cheshire contends that the English law does not recognize the doctrine of renvoi. Id. at 65 . Yet this conclusion is a denial of the necessary implication of the rule in the Annesley, Ross, and Askew cases that the English judge should apply renvoi or not according to the rule of foreign law. And the conclusion is directly contrary to what was actually done in the Annesley case. For a criticism of the English view as represented by the $A$ skew case, see Lewald, $Z u r$ Lehre der Rückverweisung im englischen Recht (I93I) 44 NIEMEYER I. The writer points out that the problem of renvoi is inescapable in the method employed by the English courts. In re Annesley, supra, is discussed in Note (Ig26) 25 MICH. L. Rev. 174, and In re Ross, supra, in (I930) 43 HARv. L. REv. 826, and (I93I) 4 CAMB. L. J. 209. The English view is supported by Professor Griswold, supra note 6.

22. Kahn puts their objection neatly. He says: "The principle of Renvoi is logically unworkable. If the rule adopted by our system is so framed that the foreign law is to be applied in its totality, including its rules of private international law, it must also be the import of the foreign rule that our law in its turn is to be applied in its totality, including our own rules of private international law. The consequence is-that in virtue of the foreign law ours is applied in its totality and in virtue of ours, the foreign law is again applied in its totality and so on and so on; a logical 'cabinet of mirrors' (Spiegelkabinet)." Kahn, Gesetzeskollisionen (I8gI) 30 JHERINGS JAHRBÜCHER I, 23, cited in Bates, supra note I5, at 3I3.

23. The distinction is clearly pointed out by Abbot, Is the Renvoi a Part of the Common Law? (1908) 24 L. Q. REv. I33, I35, I36. See also reference to this ambiguity in Harper aNd TaINTOR, CASES AND OTHER Materials on Judicial Technidue IN CoNFLICT OF LAWS (I937) 298, n. 48. Professor Griswold used the phrase, "whole law", being careful, however, to point out the ambiguity in the term. Griswold,
supra note 6 , at 1166 . 
any question exists. They feel that one who interprets the original American conflicts rule to refer to the French conflicts rule must in consistency interpret the French conflicts rule to refer back to the American conflicts rule. If this is not so, they say, then the lex domicilii will not be consistent with the lex patria. Professor Lorenzen has stated this view as follows:

"Both must refer either to the internal or material law of the foreign country or to the foreign law inclusive of its Private International Law.

'Otherwise,' as the report of the first commission of the Institute of International Law well expressed it, 'one would fall into the absurdity of having to admit that a legislative provision establishes one thing when it is applied by the national judge and an entirely different thing when it is applied by a foreign judge; that a rule of international law changes its meaning, nature, function as soon as it passes the frontiers of the State in which it was promulgated!'

There would appear to be no escape in legal theory from this circle or endless chain of references." 24

I am unable to see how logic has anything to do with this matter. We are here faced with a reason (doubtless powerful enough) why rules of private international law should be uniform; but if in fact they are different, there is no breach of logical consistency. Moreover, in the renvoi situation there is really only one judge involved, namely, the judge of the court seised of the case; and the rule of law which he must explicate before applying it is not a rule of foreign law but a domestic rule whose purpose is to resolve a conflict. In other words according to the renvoi doctrine, a French judge faced with our hypothetical case would apply French internal law while an American judge in the same situation would apply American internal law. Is this any less consistent than requiring the French judge in the given situation to apply American internal law and the American judge to apply French internal law? Each theory arrives at a result as consistent as the other. Therefore, it is difficult for me to understand why the American conflicts rule may refer to French internal law (as these writers say it does), but a supposed French conflicts rule may not refer back to American internal law.

\section{Renvoi Exceptions}

The opponents of the doctrine of renvoi have accepted it in certain types of cases. These may be indicated briefly as follows:

I. International conventions among nations having different rules of the conflict of laws. 
2. Certain cases involving the validity of marriage or divorce where hardship would result if the doctrine were not followed.

3. Rules governing the disposition of immovable property. ${ }^{25}$

These are rather important exceptions; and nothing but sheer necessity, I suppose, could induce writers on private international law to apply to these cases a doctrine which they are convinced involves a formal fallacy in logic. ${ }^{26}$ Yet I am unable to see how these writers can make such a concession and still maintain their argument that renvoi inevitably leads to a circulus inextricabilis. If they can extricate themselves from the circle when the subject matter is immovable property, may not others do as much with movable property? Are international conventions, marriage and real property dispensed from the laws of logic? Some people would answer "yes" most emphatically, but they would have in mind defiance rather than dispensation, I suppose.

If those opposed to renvoi can abide erroneous reasoning in these special instances, why not in the general case? One may not cry paradox, unless his own house of logic is in order. And in the realm of logic, it is no defense for these writers to say that another's error is worse than their own since theirs is the same kind of error. They have no exclusive license to temper logic with faith.

\section{Logic and Vicious Circles ${ }^{27}$}

We have noted that all parties seem to agree that renvoi involves a vicious circle or endless chain of references, the vast majority condemning it because of this defect (among others), the rest accepting it in spite of the difficulty. The affair has passed into the field of witticism, with the honors, as might be supposed, favoring the opponents of the theory. ${ }^{28}$ As has already been said, the writer contends that the ordinary doctrine of renvoi does not involve a vicious circle, nor indeed any logical difficulty whatever.

One of the most persistent problems in the history of logic is the problem of circular definitions. Not all circular definitions are vicious,

25. Condensed from Lorenzen, supra note 4, 27 Y ALE L. J. at 529-531. RestateMAENT, CONFLICT OF LAWS (1934) \& \&, admits renvoi in questions of title to land and the validity of a decree of divorce.

26. For a criticism of the position which accepts renvoi in certain situations only, see Note (I926) 36 YALE L. J. II4.

27. References to mathematical and logical literature on the subject of this section will be very sparing inasmuch as this literature is not of general interest to the legal profession. The writer likewise wishes to avoid the present controversies centering about the nature of self-referring propositions. This means that the conclusions here reached do not depend for their validity upon logical theory but upon the principles of legal analsyis. The use of logical materials is only for the purpose of illustration. Those who wish to explore the recent literature of this subject are referred to A BIBLIOGRAPHY of PhILOSOPHy (1933-36), published by Journal of Philosophy, New York, and INTERNATIONAL Bibliography of Philosophy (1937), published by Librairie Philosophique J. Vrin, Paris.

28. Griswold, supra note 6 , at 1167, n. 8 . 
of course, because viciousness involves a value judgment, and such judgment must refer ultimately to the purpose for which the circle was originally described. In a closed deductive system, for example, it may be logically necessary that the elements of the system be defined in terms of one another. Manifestly, however, since it is the purpose of a choice of laws rule to designate to the judge which law to use in deciding a case, a circle which defeats choice on rational grounds is vicious.

Vicious circles which involve simple circular definitions are easy to detect and give rise to little difficulty. But if the circle is concealed, one often finds it hard to discover what screw is loose in the logical conundrum. Let us consider for a moment a few familiar examples of these brain twisters prior to an attempt to generalize the problem they present.

The following paradox ${ }^{29}$ was a favorite with Bishop Taylor who used it to point the moral vanitas vanitatum: A man who had been long accustomed to put implicit faith in his dreams, one night dreamt that all dreams are vain. This was most distressing; for if all dreams are vain (thought the dreamer), then my present dream is likewise vain. Therefore it may not be believed. Therefore faith in dreams is restored. Therefore my present dream is trustworthy. Therefore dreams are vain. . . .

Take another well known example. Epimenides once had occasion to remark "All Cretans are liars." No one was disturbed until a chance acquaintance happened to remember that Epimenides was himself a Cretan. Now, if all Cretans are liars and if Epimenides is a Cretan, then, per syllogism, Epimenides is a liar. Therefore Cretans are honest. So is Epimenides. He must be believed when he says that Cretans are liars. And as he himself is a Cretan. . . .

Let us consider yet another. Recently, there was a proposal (I have been told) for the construction of a huge topographical map of the United States to be made exactly to scale and to be erected on the site of an entire county (say Pecos in the State of Texas). Rivers, mountains and plains were to be accurately represented. Every state, county, town and village was to have its place. Of course, Pecos county would be represented. It would take the form of a much reduced topographic map of the United States since there would be no part of Pecos county which would not be map. One of the most interesting features of this miniature map of the United States would be an almost microscopic reproduction of Pecos county, Texas, which upon minute examination would turn out to be an infinitesimally small, yet complete, topographic map of the United States, one of whose . . .

29. Quoted by Smith, How the Mind Falis into ERror (I923) i2. 
Finally, there is our own problem which is much the same as the others: An American conflicts rule which refers to a French conflicts rule which refers to an American conflicts rule which refers to a French conflicts rule.

The above are examples of paradoxes arising from self-referring propositions, or self-including classes. In each instance the class or the proposition contains itself as part of itself. The present dream includes itself by referring to all dreams which include the present dream. The Cretan liar includes himself when he says all Cretans are liars. Pecos county includes itself by including the United States. The American conflicts rule includes itself by including the French rule which includes the American rule.

Not all of the above paradoxes are of the same type, nor are they to be resolved in the same manner. However, in dealing with them, logicians find themselves returning to a kind of prototype which is simple to state and yet which possesses all the difficulties one could desire. It is the bare statement: This proposition is false. If one denies it, the result is: this proposition is false is false. Ergo, it seems, this proposition is true. Deny it again by saying this proposition is false is false is false, and the result appears to be: this proposition is false. Continue by denying it thrice: it's true. Now four times: it's false. And so on, in saecula saeculorum.

The scholastic resolution of this paradox is incorporated in the maxim pars propositionis non potest supponere pro toto. ${ }^{30}$ This is not a solution of the problem, of course, but is merely another way of stating it. The scholastics do not show why a part of a proposition cannot be posited for the whole. They merely indicate that one who does so invites logical disaster.

Circular statements, whether vicious or otherwise, have long received the close attention of logicians and mathematicians; and the history of logic is scattered with the débris of systems designed to avoid the difficulties these statements engender. What to do with propositions of this type-often called self-referring or exceptive propositions -is still a hotly debated subject in contemporary logic. It would be out of place for us to attempt to examine the merits of that controversy. However, pending the final outcome, we are perfectly justified in barring as illegitimate all circular definitions. That is to say, we may take it as a postulate of legal science that circular definitions are illegitimate, and insist that all who desire to go behind this fundamental assumption confine their activities to another field of intellectual discipline, to wit, logic. As Kelsen postulates for legal science, the existence of the state, refusing to allow anyone in law to challenge the validity of this legal fact, so may we postulate for private international

30. Guthrie, Paradoxes of Mr. Russell (I9I5) 6. 
law a prohibition against circular definitions in determining choice of law.

In their famous treatise on mathematical logic, Whitehead and Russell ${ }^{31}$ were faced with the necessity of solving the problems raised by self-referring propositions. Their way out of the difficulty was to postulate as invalid those propositions which involved vicious circles, and those classes which were composed of illegitimate totalities, i. e., self-including classes. "The principle," they said, "which enables us to avoid illegitimate totalities may be stated as follows:

" 'Whatever involves all of a collection must not be one of the collection'; or, conversely: 'If, provided a certain collection had a total, it would have members only definable in terms of that total, then the said collection has no total.' We shall call this the 'vicious-circle principle,' because it enables us to avoid the vicious circles involved in the assumption of illegitimate totalities . . . the imaginary sceptic, who asserts that he knows nothing, and is refuted by being asked if he knows that he knows nothing, has asserted nonsense, and has been fallaciously refuted by an argument which involves a vicious-circle fallacy. In order that the sceptic's assertion may become significant, it is necessary to place some limitation upon the things of which he is asserting his ignorance, because the things of which it is possible to be ignorant form an illegitimate totality. But as soon as a suitable limitation has been placed by him upon the collection of propositions of which he is asserting his ignorance, the proposition that he is ignorant of every member of this collection must not itself be one of the collection." 32

The same principle with respect to class inclusion is elsewhere stated by Russell as follows:

"Classes are logical fictions, and a statement which appears to be about a class will only be significant if it is capable of translation into a form in which no mention is made of the class. This places a limitation upon the ways in which what are nominally, though not really, names for classes can occur significantly: a sentence or set of symbols in which such psuedo-names occur in wrong ways is not false, but strictly devoid of meaning. The supposition that a class is, or that it is not, a member of itself, is meaningless in just that way." 33

Strangely enough, Whitehead and Russell regard their analysis as a solution of the difficulty. They postulate their trouble away. However, it should be borne in mind that the method of postulation does not solve anything. It is a self-conscious limitation of one's sphere of activity. In fact the solution advanced by Whitehead and Russell is

31. Principia Mathematica (2d ed. I927).

32. I id. at 37-38.

33. Russelt, Introduction to Mathematical Philosophy (19ig) 137. 
strikingly similar to the scholastic maxim pars propositionis non potest supponere pro toto stated as a postulate. ${ }^{34}$ Be that as it may, it is entirely legitimate for lawyers to postulate where it would be illegitimate for a logician to do the same thing. Our purpose is to avoid contradiction, not necessarily to resolve it, the resolution of generalized forms of contradiction being the business of logic and not of law.

There is one form of circular statement which the mathematician or logician would not necessarily regard as vicious, but which for the lawyer would be quite illegitimate. That is an infinite regress of definitions. ${ }^{35}$ Mathematicians and logicians are entirely at home with infinite arrays, only some of which they regard as illegitimate. Lawyers, on the contrary, develop rules, not for the purpose of generating infinite series, but in order to settle cases. Hence, what might be a perfectly adequate solution of the renvoi doctrine for a logician would help the lawyer not at all.

For example, a logician might offer the following as a solution of the problem of renvoi, his sole aim being to avoid self-referring propositions.

I. An American rule of conflict of laws of the first order directs the disposition of the case according to the provisions of foreign law.

2. If under the circumstances obtaining in (I) foreign law would have directed the disposition of a similar case according to the provisions of American law, then an American rule of conflict of laws of the second order directs the disposition of the case according to the provisions of domestic law.

3. Under the circumstances obtaining in (2), an American rule of the conflict of laws of the third order directs disposition according to foreign law.

4. Under the circumstances obtaining in (3), an American rule of the conflict of laws of the fourth order directs disposition according to domestic law. And so on.

In other words, for the purposes of logic, we could assume that our law provides us with an infinity of rules of conflict of choice of law, to wit: a rule of conflict, a rule of conflict of conflict, ${ }^{36}$ a rule of conflict of conflict of conflict, etc. No rule would contain any other since each rule would be directed to a different subject and each rule would be of a different logical order. The solution for logic would

34. GuTHRIE, op. cit. silpra note 30, cited in SMITE, op. cit. supra note 29, at I5.

35. See Lewis AND LANGFord, Syarbolic Logic (1932) 438 et seq., cited in Griswold, supra note 6 , at 1167, n. 8 .

36. Two recent writers have analyzed renvoi as a rule of this sort. "The renvoi is thus in the nature of a super conflict of laws rule-conflict of conflict of laws. It is a rule of conflict of laws on a higher logical level." HARPER AND TAINTOR, op. cit. supra note 23 , at 223 . 
merely be to indicate the infinitely expanding nature of the series thus generated. Obviously, such a result would be just as vicious for lawyers as though it contained a true logical fallacy. In other words, infinite regress of definition is no more helpful to us than a true vicious circle.

\section{Renvoi Not a Vicious Circle}

I do not believe that the ordinary doctrine of renvoi involves either a vicious circle or an infinite regress of definitions. If it did, of course, either would be enough to invalidate it.

Let us revert for a moment to our friend Smith who died in Paris. According to American law his domicile at death was France. According to French law the domicile was American. If an American court were to apply the ordinary doctrine of renvoi, it would be deemed to have referred the matter to French law, which in turn would be deemed to have returned the matter to American law. The American court would thereupon have accepted the renvoi and would apply its own law to the distribution of the estate.

As was said at the outset, one of the most serious objections to this theory has always been the assumption that it does involve some form of vicious circular or expanding statement. That is, after the renvoi from France, ordaining, it is said, the application of American law, that latter law ordains a second renvoi to France, which to be consistent must direct a third renvoi to America, and so on ad infinitum.

It is obvious that, if reference and counter reference are solely to conflict rules, infinite recurrence will set in. $X$ is defined in terms of $Y$, and $Y$ is defined in terms of $X$. Hence, at this stage of the game some indefinable must be substituted for either $X$ or $Y$. The important question here is the following: When must reference cease? How long may substitution be postponed?

One may define $X$ in terms of $Y$ and $Y$ in terms of $X$, for this merely makes $X$ and $Y$ equivalent. But since an infinite regress is to be escaped, the terms must be given meaning at this point. For if $X$ is defined once more in terms of $Y$, then $X$ is included in the definition of $X$ as a part of itself. To put the matter otherwise: If I say $X$ is $Y$ and $Y$ is $X$ and then stop, what you expect of me next is to substitute some other meaning for $X$ or for $Y$. But if $I$ say $X$ is $Y$, and $Y$ is $X$, and $X$ is $Y$, the only thing you expect next of me is to say "and so on", for I have indicated all the elements of an infinite series.

It should be clear, therefore, that reference from law to law must stop before the series becomes capable of infinite expansion, or, if we think in terms of Russell's principle, before the class includes itself as a member. The theoretical, although not the practical, objection to starting renvoi has always been the claim that there is no sound theoreti- 
cal reason for stopping. ${ }^{37}$ This position has led some to assert that the court seised of the case may not apply foreign law at all where the possibility of reference back exists, but must apply its own internal law immediately. It has led others to say that reference to foreign law means reference to foreign internal law, necessarily excluding the foreign conflict of laws rule. ${ }^{38}$ Unquestionably, each of these positions avoids the danger of infinite regress or vicious circle. Can we not have one reference back to American law in our chosen case without risking a vicious circle? May there not be one renvoi without danger of an illegitimate totality? The answer is that we may have one such reference, provided that the reference back is to American internal law. American law refers the matter to French law, and the French law refers it back to American internal law where it stops. There is no circle here at all, vicious or otherwise. We have merely a round-trip, so to speak. If, however, the reference back were to American conflict rules and American law may once more refer the matter back to French law, we should have a true case of a vicious circle or an infinite regress; for French law at this stage of the game would be defined as a class composed of American law and French law. Therefore, the American court not only can, but must, stop at the second reference, although it need not do so before the point is reached.

I know that many readers will feel that this method of procedure is like lifting oneself by one's bootstraps. We seem to be justifying a rather patent flight from a difficulty by erecting it to the dignity of a postulate. We make it a matter of principle to stop before we are hurt. But the question may still persist: granted we are going to be hurt, how can we stop? I say this in answer: to reduce a theoretical position to contradiction must always lead to its abandonment. Therefore, our logical analysis shows us that if we desire a practicable result (one free from a vicious circle) the reference back must be to internal law. It also shows us that the reference back may take place, provided reference back is to internal law. We must stop as soon as contradiction is brought to light; but when this takes place we need yield only

37. As a recent commentator put it, "having once got on the renvoi merry-go-round there is no logical reason why the forum should get off at this point rather than any other." (I937) 50 HARv. L. REv. III9, II 59.

38. "But, logically, why should the inquiry stop with the internal law of New York on the reference from the French law? Why, indeed, should the reference be to the internal law of New York and not to its conflict-of-laws rule again? In the first instance, the New York court, in seeking to apply the French law, was, by hypothesis, referred to the French conflict-of-laws rule instead of its internal laws. Why not the same character of reference upon the return? It is clear that the logical result of this reference back and forth to the conflict-of-laws rule of the respective countries would be an indefinite oscillation between the two laws." Per Winthrop, Ref., In re Tallmadge, I09 Misc. 696, 709, I8I N. Y. Supp. 336, 344 (Surr. Ct. 19I9). Should not it be at least equally clear that the reason why the reference from the French law should be to the New York internal law is the laudable purpose of avoiding "indefinite oscillation between the two laws"? Why persist in indulging one's all too human penchant for paradox? 
so much as is necessary. To repeat, abandonment need not take place until all the elements of contradiction are made out. In fact, if the position is given up before that point is reached, the reason must be something other than consistency. In other words we must stop reference and counter-reference before any law includes itself as a sub-class, but there is no logical necessity for a prior halt.

What then of those who stop with the single reference, who apply the foreign internal law after having excluded the rule of counterreference? If they do this because of fear of an infinite regress, their fear is groundless. If they venture to refer, there is no logical reason against "accepting renvoi", as the picturesque phrase goes.

A statement of the doctrine of renvoi which avoids logical difficulty may now be formulated as follows:

The French conflict of laws rule refers the court to all pertinent American law including pertinent conflict of laws rules. One of these conflict of laws rules refers the court back to pertinent French law not including the rule of law by which the first reference was made.

I see no logical difficulty in such an account of a judicial proceeding. This is, in essence, the rule of law that has been applied by the French courts for over half a century. It so happens that $I$ do not agree with the French courts when they conceive the existence of an American rule of conflicts relating to causes of which a foreign court is seised. However, this is at most a misapprehension of law (or fact) and not an error in logic. If, in the above illustration, the French courts conceived that the American law referred the matter to French conflict of laws, then logical trouble would surely ensue. Hence, from the point of view of logic, if reference back is resorted to, it must be reference back to internal law and not to conflict rules.

\section{Weiterverweisung}

So far, we have been concerned only with the problem of reference back and forth between the law of two states. It sometimes happens that the law of three or more states must be consulted in determining the choice of law. So long as the "reference on" (Weiterverweisung) is to a different system of law each time, no logical problem presents itself. The court that is so unfortunate as to be faced with such a case must follow the trail as best it may, determining its choices, whether internal law or conflicts rule, on juridical grounds alone. If, however, there occurs somewhere in the series a true renvoi or reference back (Rückverweisung) to a system of law already included in the chain of references, then the same considerations apply as obtained in a simple 
reference between two states. The logical objection to renvoi has no more validity where the case involves three or more states than where the law of only two states is in issue.

\section{Conclusion}

The reader must have observed the painful care which the writer has had to take in order to state his paradoxes. The least slip in the statement of propositions ostensibly self-referring will break the charmed circle. This, of course, is usually true of logical fallacies. They are extremely hard to put. Correspondingly, it is also difficult to be sure that we have not fallen into fallacy. This is why renvoi has always been a logical ghost not easy to lay; and the value of the foregoing analysis, if any it have, lies in its making precise the logical difficulties in the doctrine.

When reference back is resorted to, the analysis indicates that there will be no logical difficulty if the reference is back to internal law. On the other hand, reference back to the conflicts rule lands us on the logical merry-go-round. The immediate practical result of this analysis is that the logical kinks in the ordinary doctrine of renvoi can be ignored. In every such instance either the internal law of the forum or foreign internal law may be applied to the case so far as logic is concerned. Thus the whole field of choice of law is freed from the logical bugbear that has so long haunted it; and as has already been said, juridical rather than logical considerations should determine one's attitude toward the doctrine.

39. Supra note $\mathbf{5} 5$. 